\title{
Clinical Effects of Scaling With Subgingival Application of 25\% Metronidazole Alginate Base Topical Gel Towards Chronic Periodontitis Patient
}

\author{
Jelita Rindly Fachrina \\ Department of Periodontics \\ Faculty of Dentistry, Universitas Sumatera Utara \\ Medan, Indonesia \\ lita_dj2806@yahoo.com
}

\author{
Irma Ervina \\ Department of Periodontics \\ Faculty of Dentistry, Universitas Sumatera Utara \\ Medan, Indonesia
}

\author{
Hakim Bangun \\ Department of Pharmacy \\ Faculty of Pharmacy, Universitas Sumatera Utara \\ Medan, Indonesia
}

\begin{abstract}
Porphyromonas gingivalis, Bacteriodes spp., Capnocytophaga spp., and Aggregatibacter actinomycetemcomitans are bacteries that cause periodontal disease. Periodontal disease is treated by eliminating pathogen bacteries through scaling and systemic or local antibiotics. One of the local antibiotics that is effective as a periodontal treatment is metronidazole gel. A clinical quasi-experiment was done towards chronic periodontitis patients with pocket depth of 4-6mm using one group pre and post test design, with a split mouth method, one side as experimental group and the other as control. Experimental group with 20 teeth was treated by scaling and $1 \mathrm{ml}$ of $25 \%$ metronidazole alginate base topical gel was applied while the reapplication was done in the first week. On the control group, only scaling was done with 20 teeth. All clinical parameters were observed on the first visit. Clinical parameters were reobeserved during the first, second, third and fourth week of visit, while pocket depth and clinical attachment level were reassesed during the fourth week of visit. There was a decrease in plaque index, gingival index, bleeding index, pocket depth and clinical attachment level in the experimental and control group. A decreased in plaque index, pocket depth and clinical attacment level were higher in the experimental group compared to the control group. This difference is statistically significant. No inflamation and bleeding were found in the experimental and control group. There are benefits in the application of $25 \%$ metronidazolee alginate base topical gel towards chronic periodontitis patients with pocket depth of 4-6mm.
\end{abstract}

Keywords-metronidazole $25 \%$ gel, alginate, local antibiotic

\section{INTRODUCTION}

It is a mandatory to treat periodontal pockets by mechanical removal of local factors (including the calculus that harbours bacteria) and also by disrupting the subgingival plaque biofilm itself [1]. Not all patients on all sites respond uniformly and favorably to conventional mechanical therapy [2]. It is well established that the various periodontal diseases are caused by bacterial infection. The local administration of anti-infective agent, generally directly to the infected area and thus reduce possible systemic side effects [3]. Local delivery of antimicrobial in periodontal pocket may be carried out with fibers, films, micro particles and gels made of biodegradable or non-degradable polymers and have been proposed as effective methods to administer antimicrobial agents in periodontal therapy [3]

Metronidazole is also effective against anaerobe such as Porphyromonas gingivalis and Prevotella intermedia. Metronidazole is a bactericidal for anaerobic organism, and it has a role to disrupt bacterial DNA synthesis in condition with a low reduction potential [4]. Natrium alginate is natural polymer, which is biocompatible and biodegradable [5]. Alginate can be used as the medium to topically medicine because it can deliver metronidazole in gel alginate. Martina et al has seen the effectiveness of antimicrobial gel metronidazole based alginate against bacteria A.a, P.g and F.n which is pathogenic bacteria periodontal [6].

\section{MATERIALS AND METHODS}

This study is a quasi-experimental clinical research, one group pre and posttest design, with split-mouth design, the treatment was done by scaling and topical application of metronidazole gel $25 \%$ alginate based while the control side was treated with scaling treatment only. This study was conducted at the installation of RSGMP FKG USU in October 2014 - February2015. The population of this study was patients who came to 
visit the installation of Periodontics RSGMP-FKG USU. The sample of this study was taken by purposive sampling which was then taken based on the existence of certain purpose. The samples are teeth from patients who suffer chronic periodontitis and met the inclusion and exclusion criteria.

The inclusion criteria include patients with chronic periodontitis, who have 2 similar teeth on opposite sides, 4-6mm depth in periodontal pocket, ages of 30-50 years, and cooperative. Meanwhile the exclusion criteria was consumer of antibiotic for 1 month, using an anti-inflammatory mouthwash, allergic to metronidazole, has a history of systemic disease, pregnant and lactating mothers, and heavy smokers.

Patients who met the inclusion criteria were gathered and asked to sign the informed consent, questionnaires were filled out. At the initial visit, the plaque index, the gingival index, the bleeding index, depth of the pocket and the clinical attachment level in all subjects were examined. Later on, the treatment group was administered $25 \%$ alginate-based metronidazole gel application to a $1 \mathrm{ml}$ periodontal pocket using a syringe needle with dull pointed needle. The adjacent teeth were isolated by cotton, then the syringe needle was inserted into the pocket, without pressure to avoid trauma on the gingival tissue and the patient was instructed not to rinse for 2 hours. Application of $25 \%$ alginated based metronidazole gel was reapplied for the first week. The plaque index, gingival index, bleeding index, performed at first, second, third and fourth week visit was examined. Measurements were taken using index O'leary plaque, gingiva Loe and Sillness index, gingival bleeding index IPPD. The processing of the data was perfomed using a computer program of SPSS version 17 to show the difference of clinical effect of on scaling with application of subgingival gel metronidazole $25 \%$ alginate based on chronic periodontitis patients used Mann-Whitney test using a Confidence interval (CI) of $95 \%$ and statistically significant obtained if value $\mathrm{P}<$ 0,05 .

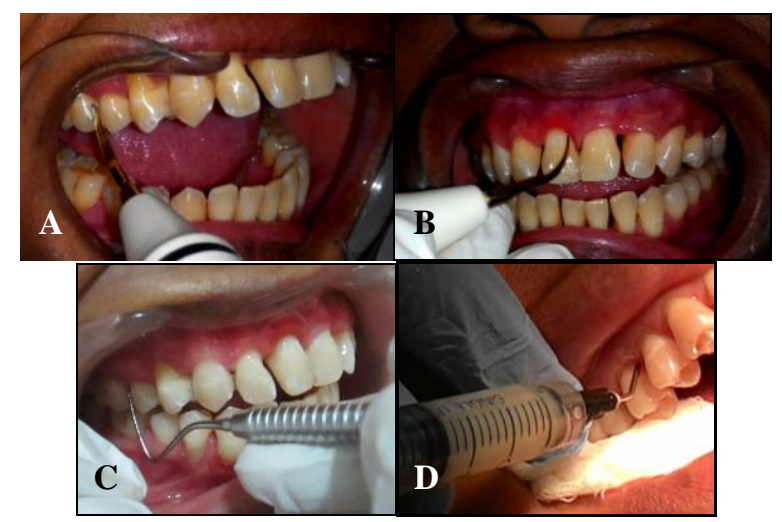

Figure 1. A and B. Scaling procedure on the control group on the initial day and the treatment group, C. Examination procedure of plaque index, gingival index, bleeding index, depth of the pocket and clinical attachment level in all subjects, and D. Application procedure of metronidazole gel $25 \%$ in alginate based on the treatment group.

\section{RESULTS}

The subject consisted of 6 patients with chronic periodontitis who received an offer at the installation of Periodontics RSGMP-FKG USU and met the inclusion and exclusion criteria. All 40 teeth which were examined were divided into 2 groups: 20 teeth (scaling $+25 \%$ metronidazole alginate based group), 20 teeth (scaling group). Mean age of the subject is 40 years ( 5 women and 1 man).

TABLE I. THE MEAN OF PLAQUE INDEX ON TEST AND CONTROL GROUPS

\begin{tabular}{|l|c|c|c|c|c|}
\hline \multirow{2}{*}{ Visit } & \multicolumn{4}{|c|}{ Group } & \multirow{2}{*}{$\begin{array}{c}p- \\
\text { value }\end{array}$} \\
\cline { 2 - 5 } & \multicolumn{2}{|c|}{ Test } & \multicolumn{2}{c|}{ Control } \\
\hline Mean & $\begin{array}{c}\text { Median } \\
\pm \mathrm{IQR}\end{array}$ & Mean & $\begin{array}{c}\text { Median } \\
\pm \mathrm{IQR}\end{array}$ & \\
\hline Before & 84,98 & $100 \pm 40$ & 87,50 & $100 \pm 38$ & 0,327 \\
\hline $\begin{array}{l}\text { First } \\
\text { week }\end{array}$ & 53,75 & $\begin{array}{c}37,50 \pm \\
75,00\end{array}$ & 66,24 & $\begin{array}{c}58,30 \pm \\
62,53\end{array}$ & 0,111 \\
\hline $\begin{array}{l}\text { Second } \\
\text { week }\end{array}$ & 14,28 & $\begin{array}{c}15,95 \pm \\
11,10\end{array}$ & 32,46 & $\begin{array}{c}35,40 \pm \\
11,82\end{array}$ & $0,000^{*}$ \\
\hline $\begin{array}{l}\text { Third } \\
\text { week }\end{array}$ & 4,43 & $\begin{array}{c}2,78 \pm \\
5,56\end{array}$ & 14,14 & $\begin{array}{c}8,30 \pm \\
16,70\end{array}$ & $0,000^{*}$ \\
\hline $\begin{array}{l}\text { Fourth } \\
\text { week }\end{array}$ & 0,94 & 0 & 7,48 & $\begin{array}{c}8,30 \pm \\
8,30\end{array}$ & $0,019^{*}$ \\
\hline
\end{tabular}

Table I, shows a decrease in the index plaque in each visit either on test group or from the control group. Index plaque shows to be greater than the test group compared to the control group. These differences are statistically significant on second visit, third visit and fourth visit $(\mathrm{p}<0.05)$.

Table II, shows the differences in the plaque index on every visit at the test and control group.

TABLE II. STATISTICAL DIFFERENCE OF PLAQUE INDEX ON EVERY VISIT BETWEEN THE TEST AND CONTROL GROUPS

\begin{tabular}{|c|l|c|c|c|c|}
\hline \multirow{4}{*}{ Test } & Visit & $\begin{array}{c}\text { First } \\
\text { week }\end{array}$ & $\begin{array}{c}\text { Second } \\
\text { week }\end{array}$ & $\begin{array}{c}\text { Third } \\
\text { week }\end{array}$ & $\begin{array}{c}\text { Fourth } \\
\text { week }\end{array}$ \\
\cline { 2 - 6 } & Before & $0.000^{*}$ & $0.000^{*}$ & $0.000^{*}$ & $0.000^{*}$ \\
\cline { 2 - 6 } & First week & & $0.000^{*}$ & $0.000^{*}$ & $0.000^{*}$ \\
\cline { 2 - 6 } & Second week & & & $0.000^{*}$ & $0.000^{*}$ \\
\cline { 2 - 6 } & Third week & & & & $0.001^{*}$ \\
\hline \multirow{5}{*}{ Control } & Before & $0.005^{*}$ & $0.000^{*}$ & $0.000^{*}$ & $0.000^{*}$ \\
\cline { 2 - 6 } & First week & & $0.000^{*}$ & $0.000^{*}$ & $0.000^{*}$ \\
\cline { 2 - 6 } & Second week & & & $0.001^{*}$ & $0.000^{*}$ \\
\cline { 2 - 6 } & Third week & & & & $0.024^{*}$ \\
\hline
\end{tabular}

In Table III, there is a decrease in the gingival index at each visit either on the test group or the control group. There is a decrease in the gingival index at the test group compared to the control group on the first and second week visits. The differences are statistically significant $(\mathrm{p}<0.05)$. On third and fourth week visits, there wasn't any inflammation on the gingiva in the both group. 
TABLE III. THE MEAN GINGIVAL INDEX ON TEST AND CONTROL GROUP

\begin{tabular}{|l|c|c|c|c|c|}
\hline \multirow{2}{*}{ Visit } & \multicolumn{4}{|c|}{ Group } & \multirow{2}{*}{$\begin{array}{c}p \\
\text { value }\end{array}$} \\
\cline { 2 - 5 } & Mean & $\begin{array}{c}\text { Median } \\
\pm \mathrm{IQR}\end{array}$ & Mean & $\begin{array}{c}\text { Median } \\
\pm \mathrm{IQR}\end{array}$ & \\
\hline Before & 1.31 & $\begin{array}{c}1.14 \pm \\
0.57\end{array}$ & 1.50 & $\begin{array}{c}1.5 \pm \\
1.00\end{array}$ & 0.190 \\
\hline $\begin{array}{l}\text { First } \\
\text { week }\end{array}$ & 0.71 & $\begin{array}{c}0.80 \pm \\
0.50\end{array}$ & 0.92 & $\begin{array}{c}1.00 \pm \\
0.13\end{array}$ & $0.040^{*}$ \\
\hline $\begin{array}{l}\text { Second } \\
\text { week }\end{array}$ & 0.24 & $\begin{array}{c}0.28 \pm \\
0.24\end{array}$ & 0.49 & $\begin{array}{c}0.42 \pm \\
0.54\end{array}$ & $0.009^{*}$ \\
\hline $\begin{array}{l}\text { Third } \\
\text { week }\end{array}$ & 0 & 0 & 0 & 0 & 1.000 \\
\hline $\begin{array}{l}\text { Fourth } \\
\text { week }\end{array}$ & 0 & 0 & 0 & 0 & 1.000 \\
\hline
\end{tabular}

On Table IV, there is a difference in gingival index at any time of visits on the test and control group. But at third week visit compared to fourth week did not find any significant differences in both groups $(\mathrm{p}<0,05)$.

TABLE IV. STATISTICAL DIFFERENCE OF GINGIVAL INDEX ON EVERY VISIT BETWEEN TEST AND CONTROL GROUPS

\begin{tabular}{|c|c|c|c|c|c|}
\hline \multirow{5}{*}{ Test } & Visit & $\begin{array}{l}\text { First } \\
\text { week }\end{array}$ & $\begin{array}{c}\text { Second } \\
\text { week }\end{array}$ & $\begin{array}{l}\text { Third } \\
\text { week }\end{array}$ & $\begin{array}{c}\text { Fourth } \\
\text { week }\end{array}$ \\
\hline & Before & $0.000^{*}$ & $0.000^{*}$ & $0.000 *$ & $0.000 *$ \\
\hline & First week & & $0.001^{*}$ & $0.000 *$ & $0.000 *$ \\
\hline & Second week & & & $0.001 *$ & $0.001 *$ \\
\hline & Third week & & & & 1.000 \\
\hline \multirow{4}{*}{ Control } & Before & $0.000^{*}$ & $0.000 *$ & $0.000^{*}$ & $0.000 *$ \\
\hline & First week & & $0.002 *$ & $0.000 *$ & $0.000 *$ \\
\hline & Second week & & & $0.000 *$ & $0.000 *$ \\
\hline & Third week & & & & 1.000 \\
\hline
\end{tabular}

Table $\mathrm{V}$, there is a decrease in bleeding index at each visit to the test and the control group. The bleeding index higher in group test compared to the control group on the first and second weeks visit. In fourth weeks visit there was not any bleeding gingiva in both groups.

TABLE V. THE MEAN OF BLEEDING INDEX ON TEST AND CONTROL GROUPS

\begin{tabular}{|c|c|c|c|c|c|}
\hline \multirow[b]{3}{*}{ Visit } & \multicolumn{4}{|c|}{ Group } & \multirow{3}{*}{$\begin{array}{c}p- \\
\text { value }\end{array}$} \\
\hline & \multicolumn{2}{|c|}{ test } & \multicolumn{2}{|c|}{ control } & \\
\hline & Mean & $\begin{array}{c}\text { Median } \\
\pm \mathrm{IQR}\end{array}$ & Mean & $\begin{array}{c}\text { Median } \\
\pm \mathrm{IQR}\end{array}$ & \\
\hline Before & 2.19 & $\begin{array}{c}2.15 \pm \\
1,44\end{array}$ & 2.19 & $\begin{array}{c}2.15 \pm \\
1.44\end{array}$ & $0.006^{*}$ \\
\hline $\begin{array}{l}\text { First } \\
\text { week }\end{array}$ & 1.27 & $\begin{array}{c}1.65 \pm \\
1.50\end{array}$ & 1.27 & $\begin{array}{c}1.65 \pm \\
1.50\end{array}$ & 0.832 \\
\hline $\begin{array}{l}\text { Second } \\
\text { week }\end{array}$ & 0.11 & $\begin{array}{c}0.00 \pm \\
0.498\end{array}$ & 0.11 & $\begin{array}{c}0.00 \pm \\
0.498\end{array}$ & $0.004 *$ \\
\hline $\begin{array}{l}\text { Third } \\
\text { week }\end{array}$ & 0.04 & 0 & 0.04 & 0 & 0.292 \\
\hline $\begin{array}{l}\text { Fourth } \\
\text { week }\end{array}$ & 0 & 0 & 0 & 0 & 1.000 \\
\hline
\end{tabular}

Table 6 , there is a difference in the bleeding index between any time visit in both groups $(\mathrm{p}<0.05)$.
TABLE VI. STATISTICAL DIFFERENCE OF BLEEDING INDEX ON EVERY VISIT BETWEEN THE TEST AND CONTROL GROUPS

\begin{tabular}{|c|c|c|c|c|c|}
\hline \multirow{5}{*}{ Test } & Visit & $\begin{array}{l}\text { First } \\
\text { week }\end{array}$ & $\begin{array}{c}\text { Second } \\
\text { week }\end{array}$ & $\begin{array}{l}\text { Third } \\
\text { week }\end{array}$ & $\begin{array}{c}\text { Fourth } \\
\text { week }\end{array}$ \\
\hline & Before & $0.000 *$ & $0.000 *$ & $0.000^{*}$ & $0.000 *$ \\
\hline & First week & & & & $0.000^{*}$ \\
\hline & Second week & & & $0.038^{*}$ & $0.011 *$ \\
\hline & Third week & & & & $0.083 *$ \\
\hline \multirow{4}{*}{ Control } & Before & $0.098 *$ & $0.000 *$ & $0.000^{*}$ & $0.000 *$ \\
\hline & First week & & $0.000 *$ & $0.000^{*}$ & $0.000^{*}$ \\
\hline & Second week & & & $0.001 *$ & $0.000 *$ \\
\hline & Third week & & & & $0.008^{*}$ \\
\hline
\end{tabular}

Table VII, there is a decrease in the average of the pocket depth value in every visit and after the fourth weeks in both groups. The statistical decrease is significant. Decrease in the depth of pocket happened higher in the mesial surface rather than distal in both groups.

TABLE VII. STATISTICAL DIFFERENCE OF POCKET DEPTH BETWEEN FIRST VISIT AND FOURTH WEEK IN BOTH GROUPS

\begin{tabular}{|c|c|c|c|c|c|c|c|c|}
\hline \multirow{3}{*}{ Visit } & \multicolumn{8}{|c|}{ Group } \\
\hline & \multicolumn{4}{|c|}{ Test } & \multicolumn{4}{|c|}{ Control } \\
\hline & $\mathrm{M}$ & $\mathrm{D}$ & V & $\mathrm{O}$ & M & $\mathrm{D}$ & V & $\mathrm{O}$ \\
\hline Before & 4.15 & 4.55 & 3.40 & 3.00 & 4.45 & 4.80 & 2.90 & 2.95 \\
\hline $4^{\text {th }}$ week & 2.50 & 2.40 & 2.40 & 2.30 & 2.70 & 2.50 & 2.20 & 2.20 \\
\hline$p$-value & $0.000^{*}$ & $0.000^{*}$ & $0.007^{*}$ & $0.010^{*}$ & $0.000^{\#}$ & $0.000^{4}$ & $0.003^{4}$ & $0.002^{\#}$ \\
\hline
\end{tabular}

Table VIII, there is no significant differences in the pocket depth between the test and control group, on the first to the fourth week visits.

TABLE VIII. STATISTICAL DIFFERENCE OF POCKET DEPTH BETWEEN TEST AND CONTROL GROUP

\begin{tabular}{|c|c|c|c|c|}
\hline Visit & Sites & Test & Control & $p$-value \\
\hline \multirow{3}{*}{ Before } & $\mathrm{M}$ & 4.15 & 4.45 & 0.250 \\
\cline { 2 - 5 } & $\mathrm{D}$ & 4.55 & 4.80 & 0.378 \\
\cline { 2 - 5 } & $\mathrm{V}$ & 3.40 & 2.90 & 0.208 \\
\cline { 2 - 5 } & $\mathrm{O}$ & 3.00 & 2.95 & 0.840 \\
\hline \multirow{3}{*}{$\begin{array}{c}\text { Fourth } \\
\text { week }\end{array}$} & $\mathrm{M}$ & 2.50 & 2.70 & 0.202 \\
\cline { 2 - 5 } & $\mathrm{D}$ & 2.40 & 2.50 & 0.760 \\
\cline { 2 - 5 } & $\mathrm{V}$ & 2.40 & 2.20 & 0.173 \\
\cline { 2 - 5 } & $\mathrm{O}$ & 2.30 & 2.20 & 0.471 \\
\hline
\end{tabular}

Table IX shows a decrease in the mean value of lost of attachment level at all the visits after the fourth week in both groups. The decreases is statistically significant.

TABLE IX. STATISTICAL DIFFERENCE OF LOSS OF ATTACHMENT BETWEEN FIRST VISIT AND FORTH WEEK IN BOTH GROUPS

\begin{tabular}{|c|c|c|c|c|c|c|c|c|}
\hline \multirow{3}{*}{ Visit } & \multicolumn{8}{|c|}{ Group } \\
\hline & \multicolumn{4}{|c|}{ Test } & \multicolumn{4}{|c|}{ Control } \\
\hline & $\mathrm{M}$ & $\mathrm{D}$ & $\mathrm{V}$ & $\mathrm{O}$ & $\mathrm{M}$ & $\mathrm{D}$ & $\mathrm{V}$ & $\mathrm{O}$ \\
\hline Before & 4.85 & 5.20 & 4.35 & 3.65 & 4.95 & 5.35 & 4.75 & 4.30 \\
\hline $4^{\text {th }}$ week & 2.80 & 3.50 & 2.80 & 2.80 & 3.50 & 3.60 & 3.50 & 3.40 \\
\hline$p$-value & $0.000^{7}$ & $0.000^{7}$ & $0.009^{*}$ & $0.034^{*}$ & $0.000^{7}$ & $0.000^{\#}$ & $0.001^{*}$ & $0.007^{7}$ \\
\hline
\end{tabular}

Table $\mathrm{X}$, there is no significant difference in lost of attachment between two groups. 
TABLE $X$. STATICTICAL DIFFERENCE OF LOSS OF ATTACHMENT BETWEEN TEST AND CONTROL GROUP

\begin{tabular}{|c|c|c|c|c|}
\hline Visit & Sites & Test & Control & $p$-value \\
\hline \multirow{4}{*}{ Before } & $\mathrm{M}$ & 4,85 & 4,95 & 0,061 \\
\cline { 2 - 5 } & $\mathrm{D}$ & 5,20 & 5,35 & 0,112 \\
\cline { 2 - 5 } & $\mathrm{V}$ & 4,35 & 4,75 & 0,170 \\
\cline { 2 - 5 } & $\mathrm{O}$ & 3,65 & 4,30 & 0,267 \\
\hline \multirow{3}{*}{$\begin{array}{c}\text { Fourth } \\
\text { week }\end{array}$} & $\mathrm{M}$ & 2,80 & 3,50 & 0,628 \\
\cline { 2 - 5 } & $\mathrm{D}$ & 3,50 & 3,60 & 0,441 \\
\cline { 2 - 5 } & $\mathrm{V}$ & 2,80 & 3,50 & 0,186 \\
\cline { 2 - 5 } & $\mathrm{O}$ & 2,80 & 3,40 & 0,064 \\
\hline
\end{tabular}

\section{DISCUSSION}

In the research, there is a decrease in plaque index, gingival index and the bleeding in both the test and the control group. In the plaque index a has a noticeable deterioration in the test group compared to the control group on visit. On the fourth visits, there is no longer bleeding and inflammatory of gingiva found in both groups.

There are reduction of the average value in the depth of pocket and lost of attachment after fourth visits in both groups. The decrease is statistically significant. But there are not any significant differences between the two groups. The result of this research in accordance with some research evaluates the effectiveness of metronidazole gel.

This is consistent with the research of Amalia, that gel metronidazole alginat has an effectiveness based on pursuing growth in some pathogenic bacteria periodontal in vitro as bacteria A.a, P.g and F.n. The obstruent mean diameter zone of all metronidazole gelis more than $15 \mathrm{~mm}$ which indicates the presence of antibacterial activity by $25 \%$ metronidazole gel and 15 $\%$ alginate based and $25 \%$ non alginate based [6].

This is research consistent with the research of Lee Dae Hyun's evaluation which described the effects of clinical and microbiological metronidazole dental gel on the subject of adult periodontitis. 179 of 109 teeth treated were divided into 4 groups which were: oral hygiene instruction care group, the metronidazole gel, subgingival scalling, and the combination of subgingival scalling and metronidazole gel. This research evaluated in the fourth week, on a sunday the twelfth and the twenty fourth week. The result shows bleeding index, plaque index, the depth of poket, lost of attachment level and the amount of bacteria present [2].

\section{REFFERENCES}

11] A.M. Pattison, G.L. Pattison, Scaling and root planning, Carranza's clinical periodontology, $11^{\text {th }}$ ed., Philadelphia: W.B. Saunders company, 2011, pp. 473 (online only).

[2] L.D. Hyun. Clinical and microbiological effects of metronidazole dental gel in treated adult periodontitis subjects. Department of Periodontology and Public Health Faculty of Dentistry the University of Hong Kong. Hong Kong, 1996, pp. 1- 90.

[3] S. Sato, M.J.V. Fonseca, J.O. Del Ciampo, J.R. Jabor, V. Pedrazzi, "Metronidazole-containing gel for the treatment of periodontitis: An in vivo evaluation," Braz. Oral Res., vol. 22(2), pp. 145-150, 2008
[4] A. Pejčić, L. Kesić, R. Obradović, D. Mirković, "Review article antibiotics in the management of periodontal disease," Scientific Journal of the Faculty of Medicine in Nišs, vol. 27(2), pp. 85-92, 2010

[5] H. Bangun, I. Ervina, D. Sinurat, Ariyana, "Formulation and in vitro evaluation of alginate based metronidazole periodontal gel," Asian Journal of Pharmaceutical and Clinical Research, vol. 7(1), pp. 223-228, 2014

[6] M. Amalia, I. Ervina, H. Bangun, "Evaluasi in vitro efektivitas antimikroba gel metronidazole berbasis alginat terhadap beberapa bakteri patogen periodontal, Tesis PPDGS Periodonsia FKG USU, 2015. 